\title{
Filozofia dośWiadczenia osobistego STEFANA PAWLICKIEgO A PEDAgOgiKa Ogólna
}

\section{Stefan Pawlicki's philosophy of personal experience and general pedagogy}

\begin{abstract}
S u m m a ry: This paper analyzes a problem that was initially solved by Stefan Zachariasz Pawlicki by means of his concept of scientific knowledge, including the distinction between philosophy, philosophical science and particular sciences. On this basis, the author shows the difference between philosophy of education and general pedagogy. Considerations are divided into three sections. First, the author explains the link between Pawlicki and pedagogics. Then, on the basis of his main philosophical work, Kilka uwag o podstawie i granicach filozofii, the concept of philosophy of personal experience is reconstructed. In the third and final section, the author considers the dependency of general pedagogy as a sub-discipline of the science(s) of education from philosophy, and the possibility of the simultaneous development of philosophy of education and general pedagogy.
\end{abstract}

Keyw ord s: Pawlicki, philosophy of personal experience, person, pedagogics, philosophy of education

Na postać Stefana Zachariasza Pawlickiego (1839-1916)ํㅜ zwróciłem uwagę przy okazji rekonstruowania dziejów recepcji i oddziaływania pedagogiki ogólnej Johanna F. Herbarta (1776-1841) w dziewiętnastowiecznej Polsce². Ówczesne moje poszukiwania doprowadziły do wniosku, że polska asymilacja koncepcji filozoficznych, psychologicznych i pedagogicznych urodzonego w Oldenburgu klasyka dokonała się, po pierwsze, za pośrednictwem herbartyzmu i, po drugie, zjednostronnym

\footnotetext{
${ }^{1}$ Zwięzłe informacje biograficzne o Pawlickim znajdują się m.in. w: Andrzej Przymusiała, „Pawlicki Stefan Zachariasz”, w: Polski stownik biograficzny, t. 25 (Wrocław: Wydawnictwo Zakładu Narodowego im. Ossolińskich 1980), 423-426; „Pawlicki Stefan”, w: Stownik polskich teologów katolickich, red. Hieronim E. Wyczawski, t. 3 (Warszawa: Wydawnictwo ATK 1982), 315-320; Bronisław Dembowski, „Spór o metafizykę. Główne poglądy na metafizykę w Polsce na przełomie XIX I XX wieku”, w: tegoż, Spór o metafizykę i inne studia z historii filozofii polskiej (Włocławek: Włocławskie Wydawnictwo Diecezjalne 1997), 24-27; Bolesław Micewski, Rafał Charzyński, „Pawlicki Stefan CR”, w: Encyklopedia katolicka, t. 15 (Lublin: Towarzystwo Naukowe Katolickiego Uniwersytetu Lubelskiego Jana Pawła II 2011), 147-148.

${ }^{2}$ Dariusz Stępkowski, „Herbart i jego myśl w Polsce. Dzieje recepcji i oddziaływania”. Artes Liberales. Zeszyty Naukowe Akademii Humanistycznej im. A. Gieysztora 1 (2007): 91-111.
} 
przeakcentowaniem pedagogiki33. Konsekwencją tego ostatniego było to, że teorie inne niż pedagogiczne drugiego następcy Kanta na Katedrze Filozofii w Uniwersytecie Królewieckim były i wciąż pozostają polskiemu czytelnikowi prawie całkowicie nieznane.

We wspomnianych powyżej dociekaniach natrafiłem na nieliczne przykłady przedstawicieli polskiej nauki drugiej połowy XIX wieku, którzy dyskutowali z teoriami Herbarta. Jeszcze mniej było takich, którzy wyrażali się o nich pozytywnie. Do owej małolicznej grupy należał między innymi Pawlicki, którego wypowiedzi o systemie Herbartowskim, w szczególności o metafizyce, odstawały wyraźnie od dominującej atmosfery krytyki i dezaprobaty. Filozof-zmartwychwstaniec z estymą pisał o spuściźnie myślowej oldenburczyka, w tym o pojednaniu między filozofią a naukami empirycznymi, do jakiego przyczynił się Herbart. Nic więc dziwnego, że korzystając z zaproszenia do udziału wdrugim Seminarium Polskiej Myśli Pedagogicznej, postanowiłem bliżej zapoznać się z poglądami Pawlickiego i rozważyć możliwość ich pedagogicznej interpretacji.

W niniejszym artykule nie zamierzam bynajmniej tropić myślowych koneksji łączących Pawlickiego i Herbarta. To zadanie wymagałoby dogłębnej znajomości metafizyki Herbartowskiej, która - jak mi się wydaje - wywarła silne piętno na sposobie filozofowania uczonego zmartwychwstańca4. Chciałbym raczej skupić się na problemie, którego zarodkowe rozwiązanie znajduje się, moim zdaniem, w wypracowanej przez Pawlickiego koncepcji poznania naukowego. Problem ten to zależność między filozofią a pedagogiką jako nauką o charakterze filozoficznym. Pytanie o własny status refleksji pedagogicznej odżyło na nowo po powrocie pedagogiki ogólnej do grona subdyscyplin nauk(i) o wychowaniu. Poszukując swojej tożsamości, musi ona rozstrzygnąć, czy powinna utożsamiać się ze stricte filozoficznymi interpretacjami wychowania, a jeżeli nie, to co ją od nich odróżnia ${ }^{5}$.

Tok argumentacji w niniejszym artykule podzielono na trzy części. Najpierw wyjaśniam związki lączące Pawlickiego z pedagogiką. Następnie na podstawie głównego dzieła naukowca-zmartwychwstańca pt. Kilka uwag o podstawie igranicach filozofii rekonstruuję jego filozofię doświadczenia osobistego

\footnotetext{
${ }^{3}$ Tamże, 110.

${ }^{4}$ Mimo dość bogatej literatury przedmiotu wyjaśnienie inspiracji filozoficznych Pawlickiego pozostaje wciąż zadaniem otwartym. Syntetyczne omówienie problematyki prac poświęconych omawianemu autorowi, które ukazały się od jego śmierci do końca lat 90. minionego stulecia zawiera artykuł Zbigniewa Kępy „Ks. Stefana Pawlickiego studium przyrody”. Studia Warmińskie 37 (2000): 425-430. Uwadze autora umknęły jednak wywodzące się z końca lat 6o. XX wieku badania Bronisława Dembowskiego na temat polskiej filozofii katolickiej, w których twórczość Pawlickiego zajmuje znaczące miejsce. Dembowski, „Spór, 38-46; tegoż, „Filozofia katolicka w latach 1863-1914”, w: tegoż, Spór o metafizykę i inne studia z historii filozofii polskiej (Włocławek: Włocławskie Wydawnictwo Diecezjalne 1997), 197-199.

${ }^{5} \mathrm{~W}$ zakresie terminologii używanej do nazwania pola powstającego między pedagogiką a filozofią panuje spora dowolność. Najczęściej spotyka się takie terminy, jak: „filozofia pedagogiki”, „filozofia pedagogiczna”, „pedagogika filozoficzna” czy „,filozofia wychowania”. Współcześnie w Polsce coraz większą popularność zdobywa wyrażenie „filozofia edukacji”, które pod wpływem myśli anglosaskiej bywa utożsamiane z pedagogiką ogólną. Dietrich Benner, Dariusz Stępkowski, „Pedagogika ogólna”, w: Encyklopedia katolicka, t. 15, 189-190.
} 
i wynikającą z niej propozycję podziału kompetencji między filozofią a naukami szczegółowymi. Na tej podstawie w trzeciej i ostatniej części rozważam koncepcję pedagogiki ogólnej jako sybdyscypliny nauk(i) o wychowaniu względnie niezależnej od filozofii.

\section{Pawlicki - ani filozofujący pedagog, ani pedagogizujący filozof}

Tytuł tego rozdziału nawiązuje do pytania, jakie za Henrykiem Baryczem powtórzył Czesław Głombik w jedynej jak dotąd monografii poświęconej w całości życiu i dziełu Pawlickiego. Pytanie to brzmiało: „kim był właściwie ten filolog filozofujący, czy też filozof filologujący?”. Należy zauważyć, że opracowanie Głombika nie było pionierskie, gdyż nieco wcześniej, aczkolwiek nie aż tak obszernie, pisał o Pawlickim i jego filozofii Bronisław Dembowski ${ }^{7}$, niemniej jednak wywołało przełom w badaniach nad spuścizną naukową tego wybitnego polskiego uczonego przełomu XIX i XX wieku. Jego postać wzbudzała zainteresowanie nie tylko z naukowych względów. Głombik w kolejnej swojej publikacji poświęconej początkom neoscholastyki polskiej pisał o filozofie-zmartwychwstańcu między innymi: „Wykładający w Krakowie Pawlicki był [...] zaliczany do rzędu najwybitniejszych platonologów i platonofilów polskich XIX i XX wieku, zyskując przy tym towarzysko opinię jednej z barwniejszych postaci w środowisku krakowskiej profesury końca XIX wieku"s.

Zapewne wskazane powyżej odrodzenie zainteresowania Pawlickim doprowadziło do utrwalenia jego renomy jako wybitnego przedstawiciela polskiej nauki i do włączenia jego spuścizny piśmienniczej do ogólnopolskiego projektu „Repozytorium Cyfrowe Instytutów Naukowych”, w którego ramach przeprowadza się digitalizację najcenniejszych pomników polskiej twórczości naukowej. Dzięki temu prace omawianego autora - zarówno te wydane drukiem, jak i te znajdujące się wciąż w rękopisach - są obecnie dostępne szerokiemu gronu zainteresowanych ${ }^{9}$. Oby ułatwiony dostęp przyczynił się nie tylko do powstania kolejnych głębokich i wnikliwych analiz, lecz również do popularyzacji idei tego otwartego na nowe prądy myślowe katolickiego uczonego.

Za jeden z pierwszych kroków w stronę upowszechnienia dorobku myślowego omawianego autora można z całą pewnością uznać konferencję pt. „Ks. Stefan Pawlicki

\footnotetext{
${ }^{6}$ Czesław Głombik, Cztowiek i historia. Studium koncepcji filozoficznej Stefana Pawlickiego (Warszawa: Państwowe Wydawnictwo Naukowe 1973), 21.

${ }^{7}$ Wspomniana powyżej już dwukrotnie książka Bronisława Dembowskiego pt. Spór o metafizykę... była jego rozprawą habilitacyjną i została po raz pierwszy wydana drukiem w 1969 roku.

${ }^{8}$ Czesław Głombik, Początki neoscholastyki polskiej (Katowice: Uniwersytet Śląski 1991), 199.

${ }^{9}$ Por. http://rcin.org.pl/dlibra/results?action=SearchAction\&skipSearch=true\&mdirids=\&server\%3Aty pe $=$ both\&tempQueryType $=-3$ \&encode $=$ false\&isExpandable $=$ on\&isRemote $=$ off\&roleId $=-3 \&$ queryType $=-$ $3 \&$ dirids $=1$ \&rootid=\&query $=$ Pawlicki+Stefan+Zachariasz\&localQueryType=-3\&remoteQueryType=-2 [dostęp: 9.05.2016].
} 
CR: człowiek nauki i wiary w służbie odnowy społecznej i duchowej”, która odbyła się w Uniwersytecie Papieskim Jana Pawła II w Krakowie 17 lutego 2016 roku $^{10}$. Znamienne jednak, że w jej programie zabrakło całkowicie wątku pedagogicznego. Czyżby było to tylko przeoczenie organizatorów, czy może rzeczywiście nie powinno się kojarzyć Pawlickiego z pedagogiką z tej choćby przyczyny, że w jego dorobku nie ma jednej pracy traktującej wprost o tej nauce?

$\mathrm{Na}$ trop możliwego rozwiązania powyższej wątpliwości naprowadza artykuł Stefana Kunowskiego Tomistyczne studia $w$ dziedzinie pedagogiki, $w$ którym autor wskazuje na wkład zmartwychwstańców w odrodzenie myśli tomistycznej w Kościele katolickim w drugiej połowie XIX wieku. Co prawda Kunowski nie wymienia Pawlickiego ani żadnego ze zmartwychwstańców z imienia i nazwiska, ani też nie interpretuje tego faktu w kontekście powstawania i rozwoju rodzimej myśli pedagogicznej, niemniej jednak można przypuszczać, że co najmniej pośrednio oddziałało to na kreowanie się tej myśli ${ }^{11}$. Współcześnie potwierdziła to Janina Kostkiewicz, która w opracowaniu systemu wychowawczego Zakonu Zmartwychwstania Pańskiego zaliczyła Pawlickiego do grona „twórców pedagogii zmartwychwstańczej”"2. Ponownie przypomniała to w monografii Kierunki i koncepcje pedagogiki katolickiej w Polsce 1918-1939 ${ }^{13}$.

Czy na podstawie przedstawionych powyżej, zdecydowanie wątłych dowodów, da się osadzić Pawlickiego wnurtach dziewiętnastowiecznej pedagogiki katolickiej w Polsce? Jak przypomniał Kunowski we wspomnianym artykule, zmartwychwstańcy na pewno przyczynili się do przywrócenia pamięci o systemie filozoficznym św. Tomasza z Akwinu przez wystosowanie do papieża Leona XIII memoriału w sprawie uczynienia tomizmu podstawą katolickiego oglądu świata. Memoriał ten poprzedził wydaną przez papieża w 1879 roku encyklikę Aeterni Patris uznającą tomizm za oficjalną filozofię katolicyzmu. Niewątpliwie fakt ten zadecydował również o powstaniu pedagogiki tomistycznej. Dominika K. Jagielska jest zdania, że: „Wpływ założycieli Zgromadzenia OO. Zmartwychwstańców na powrót do i ponowne odczytanie dzieł św. Tomasza oraz zastosowanie ich w praktyce pedagogicznej był w II połowie XX wieku i jest współcześnie niedoceniany"14. O potrzebie wyjaśnienia tego zagadnienia niech świadczy głos Jarosława Horowskiego, który w swojej rozprawie habilitacyjnej pt. Wychowanie moralne wedhug pedagogiki neotomistycznej zauważa, że Pawlicki „w swoich poglądach nie identyfikował

\footnotetext{
${ }^{10}$ Por. http://upjp2.edu.pl/?q=konferencje-sesje/konferencja-ks-stefan-pawlicki-cr-cz\%C5\%82owieknauki-i-wiary-w-s\% $5 \% 82 \mathrm{u} \% \mathrm{C}_{5} \% \mathrm{BCbie}-$ odnowy [dostęp: 9.05.2016].

${ }^{11}$ Stefan Kunowski, „Tomistyczne studia wdziedzinie pedagogiki”, w: Pastori et Magistro. Praca zbiorowa wydana dla uczczenia 5o-lecia kaptaństwa J.E. Ks. Bpa Dra P. Kahwy Profesora i Wielkiego Kanclerze KUL, red. Andrzej Krupa (Lublin: Towarzystwo Naukowe KUL 1966), 470.

12 Janina Kostkiewicz, „Zgromadzenie Zmartwychwstania Pańskiego i jego system wychowawczy”, w: Pedagogika katlickich zgromadzeń zakonnych. Historia i wspótczesność, red. tejże, t. 1 (Kraków: Oficyna Wydawnicza „Impuls” 2012), 318.

${ }^{13}$ Tejże, Kierunki i koncepcje pedagogiki katolickiej w Polsce 1918-1939 (Kraków: Oficyna Wydawnicza „Impuls” 2013), 95.

14 Dominika K. Jagielska, „Filozoficzne podstawy systemu pedagogicznego zmartwychwstańców w pismach Piotra Semenenki”. Paedagogia Christiana 2 (2013): 148.
} 
się z tomizmem"15. Tym stwierdzeniem jednak, zamiast potwierdzenia jego styczności z myśleniem pedagogicznym i pedagogiką, podważa ostatni argument.

Pozostawiając zatem tę złożoną kwestię do rozstrzygnięcia bardziej kompetentnym osobom, chciałbym wrócić do zasygnalizowanego na wstępie problemu związku łączącego filozofię i pedagogikę. Jak wykazano do tej pory, nie jest możliwe bezpośrednie rozważanie tego związu w oparciu o odnośne wypowiedzi Pawlickiego. Jedyna droga, jaka w tej sytuacji pozostaje, to analiza problemu w nawiązaniu do dzieł omawianego autora. Wydaje się, że pracą, w której kontekście może on zostać rozważony najpełniej, jest również wspomniany już traktat z 1878 roku pt. Kilka uwag o podstawie igranicach filozofii; woparciu oten tekst wnastępnym rozdziale zostanie zrekonstruowana koncepcja filozofii doświadczenia osobistego Pawlickiego i podział kompetencji między filozofię a nauki szczegółowe.

\section{Wiedza filozoficzna a nauki szczegółowe}

Kilkakrotnie już przywoływany największy współczesny znawca dorobku naukowego Pawlickiego, Czesław Głombik, uważa Kilka uwag... za dojrzalsze dzieło filozoficzne. W przywołanej powyżej monografii stwierdza, że powstało ono, gdy filozof-zmartwychwstaniec „ochłonął już z pierwszego ferworu oraz polemicznego niepohamowania świeżego konwertyty"16. Pawlicki przygotował Kilka uwag... w Rzymie na potrzeby konkursu na stanowisko profesorskie w Uniwersytecie Jagiellońskim, do którego zamierzał przystąpić. Ta sama praca została przez niego przedłożona dwukrotnie: raz na Wydziale Filozoficznym (1878), drugim razem natomiast w postępowaniu konkursowym na Wydziale Teologicznym (1882). Pierwsza próba zakończyła się niepowodzeniem z przyczyn niezależnych od Pawlickiego. Druga przyniosła angaż na pełnym etacie najpierw w Katedrze Filozofii Chrześcijańskiej, a następnie w Katedrze Teologii Fundamentalnej ${ }^{17}$.

Dla wyrażenia stanowiska filozoficznego, które zaprezentował Pawlicki w Kilku uwagach..., Głąbik używa zamiennie terminów: „filozofia osobowości”, „filozofia osoby” $\mathrm{i}$ „filozofia doświadczenia osobistego” 18 . Współcześnie terminy te nie oznaczają tego samego. Nie wchodząc jednak w dyskusję, czy ich synonimiczne potraktowanie jest zasadne czy nie, warto zapoznać się z powodem, dla którego znawca filozofii uczonego zakonnika-zmartwychwstańca dopatruje się wosobie ludzkiej wspólnego mianownika dla jego wieloletnich i rozproszonych dociekań. Odnośnie tej sprawy Głombik pisze następująco: „dla Pawlickiego osoba ludzka była tą najbardziej elementarną postacią bytu, która poprzez swą niepowtarzalną rzeczywistość, sprawdzalną w doznaniach oraz w czynnościach, stanowiła ostateczne

\footnotetext{
${ }^{15}$ Jarosław Horowski, Wychowanie moralne wedhug pedagogiki neotomistycznej (Torun: Wydawnictwo Naukowe Uniwersytetu Mikołaja Kopernika 2015), 70.

${ }^{16}$ Głombik, Człowiek, 212.

${ }^{17}$ Głombik, Początki, 168-191.

${ }^{18}$ Głombik, Czlowiek, 212-246.
} 
oparcie i punkt wyjścia dla poszukującej myśli. Pojmował ją jako byt będący nie tylko prostą sumą jej składników. Osoba jako całość - to coś więcej niż związek jej części; to ich najściślejszy związek sprawiający, że ani ciało, ani duch nie dają się z niej wyodrębnić w postaci samoistnych elementów"19. Przytoczenie tego długiego cytatu nie miało na celu wyjaśnienia, czym lub lepiej - kim jest osoba, lecz uświadomienie czytelnikowi perspektywy, z której Pawlicki prowadził swoje badania filozoficzne. Bez wątpienia nie były to analizy bytu jako bytu, lecz perspektywa na wskroś personalistyczna, mimo że nurt filozoficzny o tej nazwie w tym czasie jeszcze nie istniał.

Tłem rozważań przedstawionych przez Pawlickiego w Kilku uwagach... był konflikt między filozofią a naukami szczegółowymi, w szczególności - deprecjacja filozofii jako nie-nauki ${ }^{20}$. W celu obrony naukowego statusu „matki nauk” Pawlicki postuluje doprecyzowanie podstawowej zasady, swoistego aksjomatu, na którym da się zbudować gmach filozofii zgodnie z wymogami współczesnej naukowości. Jego zdaniem rolę fundamentu powinno w nim pełnić stwierdzenie: „wiem że jestem” ${ }^{21}$ przede wszystkim dlatego, że: „Nie masz człowieka, który nie wie że jest”22.

Bezpośredniość i oczywistość tego sądu decydują o jego mocy przekonywania i powinny zostać wykorzystane w opartej na nim filozofii-nauce. Jednocześnie jednak jest to najsłabszy punkt zaproponowanej konstrukcji. Jaką bowiem treść niesie ze sobą ten sąd? Wyjaśniając to, Pawlicki pisze: „I tu odróżnić wypada treść myślenia od aktów jego. To o czem myślę, może nie być poza myśleniem mojem, ale sam akt myślenia zapuszcza się głęboko w rzeczywistość mej osoby. Myśl każda moja będąc czynem moim, musi, skoro jestem, uczestniczyć w realności mojej. Tak więc pewnik: wiem, że jestem, łącząc byt i myślenie moje w jedną pierwotną syntezę, staje się prawdziwym fundamentem poznania, będąc i głównym aktem jego a zarazem najbliższą rzeczywistością, od której wychodzi lub do której wraca”"23.

Powyższy opis naprowadza na dwie znane z filozofii scholastycznej kategorie - reflexio in actu signato (refleksja treściowa) i reflexio in actu exercito (refleksja towarzysząca), które wostatnim czasie przypomniał i odniósł do nowożytnego dyskursu filozoficznego Wojciech Chudy24. Pierwsza z nich - refleksja treściowa mieści w sobie dane mogące pochodzić zarówno z podmiotu, jak i spoza niego. Dane te cechuje obiektywizm oraz specyficzna przedmiotowość, dzięki której mogą one być poddawane obróbce pojęciowej. W przeciwieństwie do tego główną cechą refleksji towarzyszącej jest niejako zagłębianie się podmiotu w siebie samego. Jakie

${ }^{19}$ Tamże, 226.

${ }^{20}$ Stefan Z. Pawlicki, Kilka uwag o podstawie i granicach filozofii (Kraków: Księgarnia Krzyżanowskiego 1878), 1-5.

${ }^{21}$ Tamże, 9.

${ }^{22}$ Tamże.

${ }^{23}$ Tamże, 11.

${ }^{24}$ Wojciech Chudy, Refleksja a poznanie bytu. Refleksja „in actu exercito” ijej funkcja w poznaniu metafizykalnym (Lublin: Redakcja Wydawnictw KUL 1984). 
niebezpieczeństwo grozi wówczas podmiotowi, opisał Chudy za pomocą wyrażenia „pułapka refleksji”"25. Pułapka ta polega „na pogrążaniu się reflektującego siebie umysłu we własnej immanentności” ${ }^{26}$. Wyjaśniając ją nieco bliżej, pisał: „Mowa tu o piętrach refleksji; w istocie chodzi o te wiodące w głąb świadomości, w której obrębie buduje się system odniesień i uzasadnień poznawczych"27. Największa trudność, jaka wiąże się z powstawaniem w świadomości tych układów, to ta, czy zachowują one związek z rzeczywistością, czy są tylko czczymi fantasmagoriami.

Wydaje się, że Pawlicki dogłębnie pojmował niepewność fundamentu, na jakim rozpoczął swoje budowanie. $Z$ tym większą więc przenikliwością prowadził dalszą analizę. Najpierw wyodrębnił dwa rodzaje wiedzy: bezpośrednią i pośrednią. Ta pierwsza jest ,jedyna w swym rodzaju, dana [...] każdemu bezpośrednio, wewnętrznie, a nic lepiej jej nie określa od wyrazu «samowiedza», bo każdy sam ją ma, sam o niej wie a prócz niego nikt więcej [podkr. S.Z.P.]”28. Wiedza pośrednia dotyczy tego, co dociera do podmiotu za pośrednictwem zmysłów, tekstu pisanego czy nawet wiary. W tym kontekście Pawlicki zwraca uwagę, że: „Samowiedza [...] obejmuje byt swój i jego przypadłości sposobem ontologicznym. Jest to najściślejsza synteza, bo przedmiot i podmiot poznania, rozdwajając się na powierzchni, pozostają w głębi tą samą, niepodzielną osobą"29. Choć być może wydaje się to w tym miejscu zaburzeniem toku prezentacji, należy przypomnieć, kim według filozofa-zmartwychwstańca jest człowiek i co czyni go osobą. W tym celu posłużę się cytatem, w którym Pawlicki polemizując z Kartezjuszem, stwierdza: „Człowiek nie jest połączeniem dwóch jestestw, które obojętnie obok siebie istnieją, lecz naturą jedną, w której dusza ożywia ciało, a to doskonali duszę i razem przenikają się najpoufalszą spójnią, jaką pomyśleć można w porządku przyrodzonym. Owocem tej spójni jest ludzka osoba, która nie będąc ani duszą ani ciałem, jest ich nierozerwalną jednością"3o. Ma to taki zawiązek z omawianymi powyżej dwoma rodzajami wiedzy, że oba pochodzą z jednej i tej samej osoby ludzkiej jako zróżnicowane produkty aktów poznawczych, które wniej przebiegają. Stąd wyrażenia „filozofia osoby” w odniesieniu do poglądów Pawlickiego nie należy odczytywać przedmiotowo jako dociekania, kim jest osoba, lecz podmiotowo, to znaczy jako uznania oczywistego w gruncie rzeczy faktu, że osoba wytwarza wszelką wiedzę, zarówno filozoficzną, jak i niefilozoficzną. Ta sama konstatacja odnosi się do zwrotu: „filozofia doświadczenia osobistego”.

Powyższe rozważania, zamiast doprowadzić do rozdzielenia obszarów kompetencji między filozofią i naukami szczegółowymi przez ześrodkowanie uwagi na osobie jeszcze bardziej je zunifikowały. Taki wniosek jest zarazem słuszny i nie,

${ }_{25}$ Tegoż, Rozwój filozofowania a „pułapka refleksji”. Filozofia refleksji i próby jej przezwyciężenia (Lublin: Redakcja Wydawnictw KUL 1995).

${ }^{26}$ Tamże, 11.

27 Tamże, 18.

${ }^{28}$ Pawlicki, Kilka, 12.

${ }^{29}$ Tamże.

${ }^{30}$ Tamże, 29. 
gdyż dopiero wychodząc z tego punktu, da się w pełni zrozumieć novum propozycji Pawlickiego w sprawie - mówiąc bardziej ogólnie - klasyfikacji nauk. Ku tej propozycji zmierzają dalsze rozważania.

Podobnie jak Herbart, Pawlicki rozróżnia „ja” i „to, co moje”. O ile jednak niemiecki filozof wzbrania się przed definiowaniem „ja”, uzasadniając, iż droga do samopoznania prowadzi przez dialog toczący się w nieskończoność między „ja podmiotowym" a ,ja przedmiotowym" ${ }^{11}$, o tyle Pawlicki uważa takie podejście za błędne, twierdząc, że „bezpośrednio znam byt własny i czyny własne, pośrednio znam byt obcy i czyny obce" ${ }^{32}$. To stanowi dla niego podstawę do wyodrębnienia dwóch rodzajów doświadczenia: bezpośredniego i pośredniego. Ponieważ „byt obcy i czyny obce” mogą zostać zgłębione tylko z pomocą pośredników, podmiot, poznając je, gromadzi wiedzę na ich temat w postaci nauk szczegółowych. Odnośnie do tego Pawlicki pisze: „Nasamprzód wiedza pośrednia rozpada się na dwie olbrzymie dziedziny historycznych nauk i przyrodzonych, według tego, czy ludzkiemi czynami zajmują się, czy przyrodą. [...] Jedne i drugie w tem do siebie podobne, że zajmują się bytem obcym, który myślącemu podmiotowi dany jest za pośrednictwem zmysłów lub mowy"33. Liczba nauk, które mogą powstać w ten sposób jest właściwie nieskończona. W odróżnieniu do tego: „Wiedza bezpośrednia daleko mniejszą liczbę nauk rodzi, ale za to są pewniejsze"34. Pierwszą wśród nich jest oczywiście filozofia, Pawlicki jest jednak zdania, że na doświadczeniu wewnętrznym i wiedzy z niego wynikającej da się zbudować inne jeszcze nauki, takie jak matematyka czy fizyka. Odwołuje się przy tym do wyrażenia a priori, któremu Kant nadał, jego zdaniem, nowe i niewłaściwe znaczenie, a mianowicie „przed wszelkim doświadczeniem”35. Postulując powrót do Arystotelesowskiego rozumienia aprioryczności, która nie znaczy nic innego jak tylko „tłumaczyć skutek przez przyczynę" ${ }^{6}$, Pawlicki twierdzi, że nauki nabudowujące na doświadczeniu bezpośrednim znajdują się $\mathrm{w}$ pewnym sensie $\mathrm{w}$ uprzywilejowanej pozycji: przyczyny zjawisk, które badają i interpretują, są im dane nie dzięki jakiemuś pośrednictwu, lecz wprost. To z kolei jest powodem ich podwójnej przewagi nad naukami szczegółowymi: po pierwsze, brak metody poznania i, po drugie, absolutna pewność wniosków37.

Z tego samego podziału doświadczenia na bezpośrednie i pośrednie da się, moim zdaniem, wyciągnąć wnioski o możliwościach i granicach nie tylko filozofii czy nauk podobnie jak ona opartych na pierwszym rodzaju doświadczenia, lecz również nauk szczegółowych, które „skazane” są na okrężną drogę dochodzenia do prawdy.

${ }^{31}$ Dariusz Stępkowski, Pedagogika ogólna i religia. (Re)konstrukcja zapomnianego wątku na podstawie teorii Johanna F. Herbarta i Friedricha D.E. Schleiermachera (Warszawa: Towarzystwo Naukowe Franciszka Salezego 2010), 67-76.

${ }^{32}$ Pawlicki, Kilka, 40.

${ }^{33}$ Tamże, 42-43.

${ }^{34}$ Tamże, 43.

35 Tamże, 45 .

${ }^{36}$ Tamże.

${ }^{37}$ Tamże, 46-48. 
Tych dwóch typów doświadczenia nie należy jednak traktować jako rozłącznych, wprost przeciwnie - akty poznawcze podmiotu są jednocześnie doświadczaniem tego, co stanowi przedmiot poznania, jak i samego podmiot poznającego. Stąd też nie należy odseparowywać od siebie obszarów czy zakresów kompetencji przysługujących filozofii i naukom szczegółowym. Przeciwnie, te obszary z racji wspólnego zakotwiczenia w osobie ludzkiej częściowo się pokrywają. $Z$ drugiej strony jednak nie oznacza to, że da się je zredukować czy sprowadzić do siebie. Wyjaśnieniu tej sprawy na przykładzie filozofii wychowania i pedagogiki ogólnej jest poświęcony następny podrozdział.

\section{Filozofia wychowania czy pedagogika ogólna?}

Wspomniany na wstępie problem, w którego rozwiązaniu może pomóc naszkicowana w poprzedniej części koncepcja nauki Pawlickiego, dotyczy odmienności pedagogiki ogólnej i filozofii wychowania. Inspiracji do namysłu nad tą sprawą dostarcza lektura artykułu Krzysztofa Jakubiaka i Romana Lepperta pt. Sposoby rozumienia filozofii wychowania w polskiej pedagogice XIX $i$ XX wieku ${ }^{38}$. Autorzy postawili sobie za cel prześledzenie „znaczeń nadawanych terminowi «filozofia wychowania»"39. Po przestudiowaniu pokaźnej liczby klasycznych dzieł literatury pedagogicznej polskiej oraz obcojęzycznej (przede wszystkim niemieckiej) Jakubiak i Leppert doszli do przekonania, że większość autorów uważa pedagogikę ogólną i filozofię wychowania za terminy równoważne, a nawet identyczne. „Pytając o filozofię wychowania, pytamy o pedagogikę ogólną"40. Żeby to uzasadnić, dwójka bydgoskich pedagogów przytoczyła słowa Stefana Wołoszyna: „Pedagogika ogólna, chętnie nazywana również filozofią wychowania (philosophy of education), wyrasta z przekonania, że nie ma wiedzy i poglądów naukowych bez prześwietlającego je pierwiastka filozoficznego - co więcej, żywotność i doniosłość problematyki filozoficznej w obrębie konkretnej dyscypliny naukowej świadczy o żywotności i wadze danej nauki, jest świadectwem tego, że dana nauka widzi, stawia i stara się rozwiązywać coraz to nowe zagadnienia istotne i ważne tak dla poznania jak i praktyki życiowej"41.

Jak wynika z przytoczonej powyżej wypowiedzi Wołoszyna, w analizowanej sprawie decydujące znaczenie ma filozoficzność pedagogiki. $Z$ tym jednak wiąże się największy problem, gdyż jak dotąd nie ma jednomyślności odnośnie do tego, na czym ów (konieczny) filozoficzny charakter wiedzy pedagogicznej miałby polegać. Co

\footnotetext{
${ }^{38}$ Krzysztof Jakubiak, Roman Leppert, „Sposoby rozumienia filozofii wychowania w polskiej pedagogice XIX i XX wieku”, w: Idee pedagogiki filozoficznej, red. Sławomir Sztobryn, Bogusław Śliwerski, t. 1 (Łódź: Wydawnictwo Uniwersytetu Łódzkiego 2003), 223-239.

${ }^{39}$ Tamże, 223.

${ }^{40}$ Tamże, 239.

${ }^{41}$ Stefan Wołoszyn, Nauki o wychowaniu $w$ Polsce $w X X$ wieku. Próba zarysu encyklopedycznego (Warszawa: Oficyna Wydawnicza Latona 1993), 89. Cyt. za: tamże.
} 
prawda ciągle na nowo podejmuje się debatę na ten temat, ale daremne wydaje się oczekiwanie, że da się kiedykolwiek ją rozstrzygnąćc ${ }^{42}$.

Powodów powyższego stanu rzeczy Paulina Sosnowska słusznie dopatruje się w obopólnym braku kompetencji - filozoficznych u pedagogów i pedagogicznych u filozofów43. Inną przyczyną jest jej zdaniem „zbyt naiwne imało subtelne transponowanie teorii filozoficznych na teren edukacji. Wina [za to - dop. D.S.] leży zarówno po stronie filozofów, jak i pedagogów. Ci drudzy z filozofią edukacji często utożsamiają system celów, zasad czy wartości, którym intelektualnie i emocjonalnie hołdują. Filozofowie z kolei zbyt często traktują filozofię edukacji i samą edukację po macoszemu i wypowiadając się na jej temat (co czynią zresztą rzadko), rezygnują z właściwiej im skądinąd precyzji i dyscypliny intelektualnej" 44 .

Inaczej na tę samą sprawę można spojrzeć, gdy się cofnie do rozważań przedstawionych w poprzednim podrozdziale. Przyjmując za Pawlickim „doświadczenie osobiste” jako wspólną podstawę filozofii, nauk filozoficznych i nauk szczegółowych (w tym przypadku chodzi o pedagogikę ogólną), można dość łatwo wskazać kryterium umożliwiające oddzielenie dwóch pierwszych od trzeciej. Tym kryterium jest rodzaj doświadczenia - bezpośredniego lub pośredniego. W pierwszym przypadku będzie chodziło o naukę stricte filozoficzną, która, działając we właściwym sobie zakresie, przedmiotem eksploracji poznawczej będzie czynić wychowanie. Nauka ta może przybierać różne nazwy: „filozofia pedagogiki”, „filozofia pedagogiczna”, „pedagogika filozoficzna”, „filozofia wychowania” czy „filozofia edukacji”.

Cytowana powyżej Sosnowska wyodrębniła cztery sposoby prowadzenia namysłu filozoficznego nad wychowaniem: „Można [...], po pierwsze, prostodusznie i staroświecko skoncentrować się na poglądach wychowawczych wielkich filozofów i je analizować. Po drugie, niekiedy poszerza się nieco horyzont namysłu i przygląda temu, co dany autor miał do powiedzenia w kwestiach wychowaniu pokrewnych, takich jak kultura czy społeczeństwo, po czym wyprowadza się z nich wnioski dotyczące wychowania. Po trzecie, niekiedy konkretny problem z dziedziny pedagogiki, który nie może zostać rozwiązany środkami żadnej z nauk szczegółowych, przenosi się na teren filozofii” 45 . Czwarty i ostatni sposób, który autorka osobiście preferuje, polega na tym, żeby „zobaczyć [podkr. P.S.] wychowanie w filozofii bezpośrednio z nim zupełnie niezwiązanej. Znaczy to ujrzeć w filozofii człowieka, kultury, a nawet w filozofii bytu, warunki możliwości zarówno samego wychowania, jak i jego teorii” ${ }^{6}$. Niewątpliwie

\footnotetext{
${ }^{42}$ Problemowi związku między filozofią a pedagogiką poświęcone były m.in. następujące publikacje: Filozofia pedagogice. Pedagogika filozofii, red. Maria Dudzikowa. „Colloquia Communia” numer specjalny 2 (2003); Filozofia a pedagogika: studia i szkice, red. Piotr Dehnel, Piotr Gutowski (Wrocław: Wydawnictwo Naukowe DSWE TWP 2005); Sławomir Sztobryn, Stan filozofii wychowania w Polsce na przetomie XX/XXI wieku [w druku, 2016].

${ }^{43}$ Paulina Sosnowska, Filozofia wychowania $w$ perspektywie Heideggerowskiej różnicy ontologicznej (Warszawa: Wydawnictwa Uniwersytetu Warszawskiego 2009), 9.

${ }^{44}$ Tamże.

${ }^{45}$ Tamże, 11.

${ }^{46}$ Tamże.
} 
prace Pawlickiego (nie tylko filozoficzne) dostarczają materiału, na którym ten sposób uprawiania filozofii wychowania może zostać przećwiczony.

Wracając jednak do rozwarstwienia nauk opartego na różnicy między dwoma rodzajami „doświadczenia osobistego”, pedagogikę ogólną należałoby zakwalifikować do nauk szczegółowych. Zgodnie z tym przyporządkowaniem jej analizy mają za przedmiot doświadczenie pośrednie, którego jednak Pawlicki w Kilku uwagach... nie opisał tak wnikliwie jak bezpośredniego. Pomimo tego można jednak wysnuć pewne wnioski co do kompetencji pedagogiki ogólnej jako nauki szczegółowej.

Pisząc o zadaniach filozofii wobec nauk szczegółowych, Pawlicki wymienia dwa zasadanicze: po pierwsze, przeprowadzanie krytyki stosowanych w niej pojęć, po drugie zaś, poszukiwanie właściwej formy dla treści, które ta nauka gromadzi47. W zastanawiająco ścisły sposób oba dwa zadania korespondują z dwoma postulatami Herbarta wobec nowej dyscypliny wiedzy, do której w 1806 roku napisał pierwszy podręcznik. We wstępie do Pedagogiki ogólnej wywiedzionej z celu wychowania żąda on: „Lepiej [...], aby pedagogika uświadomiła sobie jak najdokładniej swoje rodzime pojęcia i wypielęgnowała samodzielną myśl; przez to stałaby się sama ośrodkiem zakresu badań i uniknęła niebezpieczeństwa podlegania rządzom obcej zwierzchności" 48 . Zwierzchnością, o której tu mowa, jest filozofia. Herbart nie wzywa jednak do rewolty, lecz do świadomego budowania pedagogiki jako autonomicznej dyscypliny wiedzy. „Dla samej filozofii będzie to miłe, jeżeli inne nauki samodzielnie będą się do niej odnosiły" 49 .

\section{Zakończenie}

$\mathrm{Z}$ całą pewnością Pawlicki nie był pedagogiem. Jednak jego koncepcja nauki wnika głęboko w problem, który do dziś trapi pedagogikę ogólną i wydaje się nie do rozwiązania. Problemem tym jest kwestia filozoficzności myślenia ogólnopedagogicznego oraz jego niezależności wobec „matki nauk”. Na podstawie rekonstrukcji powiązań zachodzących między filozofią i naukami filozoficznymi a naukami szczegółowymi, udało się stwierdzić, że autonomiczny status pedagogiki ogólnej w bezpośredni sposób wynika z teoriopoznawczych dociekań autora Kilku uwag...

Stre s z c z e ni e: W prezentowanym artykule prześledzono problem, którego zarodkowe rozwiązanie zostało wypracowane przez Stefana Zachariasza Pawlickiego w koncepcji poznania naukowego i wynikającego z niej rozróżnienia między filozofią i naukami filozoficznymi a naukami szczegółowymi. Na tej podstawie autor artykułu dąży do wskazania różnicy między filozofią wychowania a pedagogiką ogólną. Tok argumentacji został podzielony na trzy części. Najpierw wyjaśniono związki łączące Pawlickiego z pedagogiką. Następnie na podstawie głównego dzieła

\footnotetext{
${ }^{47}$ Pawlicki, Kilka.

${ }^{48}$ Johann F. Herbart, Pedagogika ogólna wywiedziona z celu wychowania (Warszawa: Wydawnictwo Akademickie „Żak” 2007), 22.

${ }^{49}$ Tamże.
} 
naukowca-zmartwychwstańca pt. Kilka uwag o podstawie i granicach filozofii zrekonstruowano jego filozofię doświadczenia osobistego i wynikającą z niej propozycję podziału zakresu kompetencji między filozofią a naukami szczegółowymi. Po czym w trzeciej i ostatniej części rozważono koncepcja zależność pedagogiki ogólnej jako subdyscypliny nauk(i) o wychowaniu od filozofii oraz możliwość równoczesnego rozwijania filozofii wychowania i pedagogiki ogólnej.

Słowa kluczowe: Pawlicki, filozofia doświadczenia osobistego, osoba, pedagogika, filozofia wychowania

\section{Bibliografia}

Benner, Dietrich, Dariusz Stępkowski. „Pedagogika ogólna”. W: Encyklopedia katolicka, t. 15, 189-190. Lublin: Towarzystwo Naukowe Katolickiego Uniwersytetu Lubelskiego Jana Pawła II, 2011.

Chudy, Wojciech. Refleksja a poznanie bytu. Refleksja „in actu exercito” ijej funkcja wpoznaniu metafizykalnym. Lublin: Redakcja Wydawnictw KUL, 1984.

Chudy, Wojciech. Rozwój filozofowania a „putapka refleksji”. Filozofia refleksji i próby jej przezwyciężenia. Lublin: Redakcja Wydawnictw KUL, 1995.

Dembowski, Bronisław. „Filozofia katolicka w latach 1863-1914”. W: tegoż, Spór o metafizykę i inne studia z historii filozofii polskiej, 192-211. Włocławek: Włocławskie Wydawnictwo Diecezjalne, 1997.

Dembowski, Bronisław. „Spór o metafizykę. Główne poglądy na metafizykę w Polsce na przełomie XIX I XX wieku". W: tegoż, Spór o metafizykę i inne studia z historii filozofii polskiej, 17-164. Włocławek: Włocławskie Wydawnictwo Diecezjalne, 1997.

Filozofia a pedagogika: studia i szkice, red. Piotr Dehnel, Piotr Gutowski. Wrocław: Wydawnictwo Naukowe DSWE TWP, 2005.

Filozofia pedagogice. Pedagogika filozofii, red. Maria Dudzikowa. „Colloquia Communia” numer specjalny 2 (2003).

Głombik, Czesław. Cztowiek i historia. Studium koncepcji filozoficznej Stefana Pawlickiego. Warszawa: Państwowe Wydawnictwo Naukowe, 1973.

Głombik, Czesław. Początki neoscholastyki polskiej. Katowice: Uniwersytet Śląski, 1991.

Herbart, Johann F. Pedagogika ogólna wywiedziona z celu wychowania. Warszawa: Wydawnictwo Akademickie „Żak”, 2007.

Horowski, Jarosław. Wychowanie moralne wedhug pedagogiki neotomistycznej. Toruń: Wydawnictwo Naukowe Uniwersytetu Mikołaja Kopernika, 2015.

Jagielska, Dominika K. „Filozoficzne podstawy systemu pedagogicznego zmartwychwstańców w pismach Piotra Semenenki”. Paedagogia Christiana 2 (2013): 145-161.

Jakubiak, Krzysztof, Roman Leppert. „Sposoby rozumienia filozofii wychowania w polskiej pedagogice XIX i XX wieku”. W: Idee pedagogiki filozoficznej, red. Sławomir Sztobryn, Bogusław Śliwerski, t. 1, 223239. Łódź: Wydawnictwo Uniwersytetu Łódzkiego, 2003.

Kępa, Zbigniew. „Ks. Stefana Pawlickiego studium przyrody”. Studia Warmińskie 37 (2000): 425-430.

Kostkiewicz, Janina. „Zgromadzenie Zmartwychwstania Pańskiego ijego system wychowawczy”. W: Pedagogike katolickich zgromadzeń zakonnych. Historia i wspótczesność, red. Janina Kostkiewicz, t. 1, 309-334. Kraków: Oficyna Wydawnicza „Impuls”, 2012. 
Kostkiewicz, Janina. Kierunki i koncepcje pedagogiki katolickiej w Polsce 1918-1939. Kraków: Oficyna Wydawnicza „Impuls”, 2013.

Kunowski, Stefan. „Tomistyczne studia w dziedzinie pedagogiki”. W: Pastori et Magistro. Praca zbiorowa wydana dla uczczenia 5o-lecia kaptaństwa J.E. Ks. Bpa Dra P. Kahwy Profesora i Wielkiego Kanclerze KUL, red. Andrzej Krupa, 469-488. Lublin: Towarzystwo Naukowe KUL, 1966.

Micewski, Bolesław, Rafał Charzyński. „Pawlicki Stefan CR”, w: Encyklopedia katolicka, t. 15, 147-148. Lublin: Towarzystwo Naukowe Katolickiego Uniwersytetu Lubelskiego Jana Pawła II, 2011.

Pawlicki, Stefan Z. Kilka uwag o podstawie i granicach filozofii. Kraków: Księgarnia Krzyżanowskiego, 1878.

Przymusiała, Andrzej. „Pawlicki Stefana Zachariasz”, w: Polski stownik biograficzny, t. 25, 423-426. Wrocław: Wydawnictwo Zakładu Narodowego im. Ossolińskich, 1980.

Sosnowska, Paulina. Filozofia wychowania w perspektywie Heideggerowskiej różnicy ontologicznej. Warszawa: Wydawnictwa Uniwersytetu Warszawskiego, 2009.

Stępkowski, Dariusz. „Herbart i jego myśl w Polsce. Dzieje recepcji i oddziaływania”. Artes Liberales. Zeszyty Naukowe Akademï Humanistycznej im. A. Gieysztora 1 (2007): 91-111.

Stępkowski, Dariusz. Pedagogika ogólna ireligia. (Re)konstrukcja zapomnianego wątku na podstawie teorii Johanna F. Herbarta i Friedricha D.E. Schleiermachera. Warszawa: Towarzystwo Naukowe Franciszka Salezego, 2010.

Sztobryn, Sławomir. Stan filozofii wychowania w Polsce na przełomie XX/XXI wieku [w druku, 2016].

Wołoszyn, Stefan. Nauki owychowaniu w Polsce wXX wieku. Próba zarysu encyklopedycznego. Warszawa: Oficyna Wydawnicza Latona, 1993. 